\title{
A Flow Szinkronizáció Kérdőív pszichometriai jellemzói: reliabilitás- és validitásvizsgálat
}

\author{
MAGYARÓDI TÍMEA* - OLÁH ATTILA \\ Eötvös Loránd Tudományegyetem, Pedagógiai és Pszichológiai Kar, \\ Pszichológiai Intézet, Budapest
}

(Beérkezett: 2016. január 25.; elfogadva: 2016. április 17.)

Elméleti háttér: A humán interakciók során szinkronizációs, koordinációs tendencia figyelhető meg, amely akár az élmények szintjén is megvalósulhat. Korábbi eredmények szerint a közösen végzett tevékenységekben intenzívebb áramlat élmény (flow) tapasztalható, mint egyedül. A jelenség múködéséhez hozzájáruló tényezőket flow szinkronizációnak neveztük, amelynek mérésére kidolgoztuk a Flow Szinkronizáció Kérdoóivet (FSZK).

Cél: Jelen kutatás célja az FSZK pszichometriai jellemzőinek, a skálák belső megbízhatóságának és validitásának vizsgálata.

Módszerek: A kutatás keresztmetszeti módon, különböző konstruktumokat (flow, a diádikus interakció sajátosságai, szorongás, éntudatosítás) vizsgáló kérdőívek segítségével történt, az adatfelvétel online felületen zajlott. A vizsgálatban 367 felnőtt vizsgálati személy vett részt (az életkor átlaga 28,5 év, SD =12,89 év).

Eredmények: Az eredmények szerint az FSZK skáláinak belső megbízhatósága megfelelő, az ötfaktoros struktúra igazolt $\left(\chi^{2}(336)=857,27, p<0,001, C M I N / d f=2,55\right.$, TLI $=0,900$, CFI = 0,911, RMSEA = 0,065). A kérdőív kritériumvaliditása az elvártak szerint alakult: a flow állapottal, a diádikus interakció szubjektív élményeivel, a kíváncsisággal a konvergens validitást igazoló összefüggéseket kaptunk, míg az éntudatosítás, feszültség, szorongás faktoraitól és a düh tényezőitől különböző konstruktumnak bizonyult.

Következtetések: Az eredmények szerint tehát az FSZK alkalmas a flow szinkronizáció konstruktumának megragadására, megbízható és érvényes mérésére.

Kulcsszavak: Flow Szinkronizáció Kérdőív, reliabilitás, validitás

\section{Elméleti háttér}

A pozitív pszichológia mozgalma a jól múködés feltételeinek empirikus kutatásokkal történő meghatározását, továbbá a kutatási eredményekre épített intervenciók kidolgozását túzte ki célul (Seligman \& Csikszentmihalyi, 2000). Az optimális múködést, fejlődést támogatja Csikszentmihalyi Mihály

\footnotetext{
* Levelező szerző: Magyaródi Tímea, Eötvös Loránd Tudományegyetem, Pszichológiai Intézet, 1064 Budapest, Izabella u. 46. E-mail: magyarodi.timea@ppk.elte.hu
} 
áramlat élmény (flow) koncepciója is (Csikszentmihalyi, 1975). Az áramlat olyan szubjektív élményt takar, amelyról az emberek önbeszámolói alapján értesülhetünk, amikor valaki annyira elmerül az aktuálisan végzett tevékenységben, hogy semmi másra nem koncentrál, kizárólag a számára kihívást jelentő, de teljesíthető feladat végzésére (Csikszentmihalyi, 1990). A humanisztikus pszichológia hagyományaihoz (Maslow, 1962; Rogers, 1961) illeszkedve a flow elmélet feltételezi, hogy az ember a saját, szubjektív élményvilágában él, és egyénileg értelmezi a tapasztalatait (Hektner, Csikszentmihalyi, \& Schmidt, 2007; Sheldon \& Kasser, 2001).

Az áramlat alapfeltételeként leginkább a magas szintú kihívás és a megoldásához, kezeléséhez szükséges magas szintú készségek közötti egyensúlyt azonosítják (Csikszentmihalyi \& Selega Csikszentmihalyi, 1988; Csikszentmihalyi, 1975, 1990), amely sajátos az egyénre jellemzó mértékben, az adott tevékenység kontextusában. További proximális feltétel a tiszta cél megléte, valamint a folyamatos visszajelzés az előrehaladásról (Nakamura \& Csikszentmihalyi, 2002), majd az élmény létrejöttével számos faktor azonosítható a dinamika jellemzésére: a tevékenység feletti kontroll érzése, az éntudatosítás elvesztése, a megváltozott időérzékelés, a figyelem könnyed koncentrálása (Csikszentmihalyi \& Nakamura, 2010), valamint az autotelikusság (azaz a tevékenység önmagáért való végzése).

Az optimális élmény Csikszentmihalyi (1990) szerint univerzális, azaz nemtől, kortól, kultúrától függetlenül ugyanazok a feltételek szükségesek a létrejöttéhez, valamint ugyanaz a dinamika jellemző rá, azonban a kutatások alapján elmondható, hogy bizonyos demográfiai jellemzők esetében, kontextusokban a flow élmény különböző feltételei hangsúlyosabbak, valószínúsítik az élmény átélését. Például szociális interakció során az átélt flow egyenesen arányos az észlelt kihívásszinttel, az együttmúködés mértékével, a visszajelzés azonnaliságával, tisztaságával, továbbá a készségek szintjével (Magyaródi \& Oláh, 2015a).

A flow szociális kontextusban való vizsgálatát Csikszentmihalyi vetette fel (Csikszentmihalyi \& Selega Csikszentmihalyi, 1988), a téma pedig egy egyre növekvő kutatási területet jelöl, mégis az eddigi hipotézisek az áramlat társas múködésére vonatkozóan leginkább olyan kutatások melléktermékei, amelyek főként az élmény egyéni vonatkozásaira koncentrálnak (Magyaródi \& Oláh, 2015b).

A flow szinkronizáció a közös interakcióban részt vevő partnerek flow élményének múködését szintetizálja, az élmény közben átélt társas interakciónak a flow élményre ható sajátosságait kiemelve. Együttmúködő, kihívást jelentó helyzet során, diádikus helyzetben flow szinkronizációnak tekintjük tehát az áramlat élmény átélése közben azokat az interakcióból fakadó sajátosságokat (úgymint összhang, élmény, motiváció, koordináció), amelyeket a személy szubjektív élménykomponensekként tapasztal, amely- 
nek eredménye az élmény intenzitásának növekedése, a másik személlyel való kölcsönös egymásra hatás. A jelenség mérésére kidolgoztuk a Flow Szinkronizáció Kérdőívet (FSZK; Magyaródi \& Oláh, 2015b).

Az FSZK tételei az elméleti megalapozottságon túl empirikus módon, a résztvevők beszámolóinak kvalitatív feldolgozása alapján kerültek megalkotásra, bővítésre, négy fejlesztési fázis során. A négy kutatásból az első kettóben kísérleti módszertant alkalmaztunk (Magyaródi, 2014), összesen 160 fő, 80 diád vizsgálatával. A flow indukciós módszereket alapul véve (Moller, Meler, \& Wall, 2010; Rich, 2013; Ulrich, Keller, Hoenig, Waller, \& Grön, 2014) idéztünk elő olyan szituációkat, amelyek a résztvevők beszámolói szerint is megfeleltek a flow élmény feltételeinek (Nakamura \& Csikszentmihalyi, 2002), a laboratóriumi helyzet ellenére magas ökológiai validitással bíró eszközöket használva (Kaye \& Bryce, 2012; McMahan, Ragan, Leal, Beaton, \& Bowman, 2011). A kísérletben a vizsgálati személyek közös interakciós helyzetben vettek részt, páros együttmúködés során oldották meg a feladatot, amely után beszámoltak az átélt élményről, a flow élmény és a kapcsolódó társas vonatkozás tekintetében is. A kérdőív struktúrájának véglegesítésére, a nagyobb mintaelemszám elérése érdekében két kérdőíves kutatást végeztünk, amelyek eredményeként megszületett a véglegesnek tekintett, ötfaktoros Flow Szinkronizáció Kérdőív (Magyaródi \& Oláh, 2015b), amelyet egy konkrét helyzetben tapasztalt élmény utólagos értékelésére használunk, közvetlenül a tevékenység végzése után, ahogyan a kísérleti módszertannal végzett kutatásainkban is használtuk, vagy pedig egy tevékenységre való visszagondolás segítségével, retrospektív értékelés útján. A kérdőív segítségével az áramlat élmény dinamikája bővítve vizsgálható a társas helyzetekben tapasztalt flow élményhez kapcsolódóan, a társas interakció faktoraival kiegészítve.

Az FSZK 28 tételes, önbeszámolós mérőeszköz, az empirikus és elméleti alapokon történő fejlesztési folyamat eredményeként öt látens faktort különböztet meg, a kihívást jelentő közös tevékenység, a személyes, együttmúködő jellemzők, valamint a motivációs hatások perspektívájából:

1. Hatékonyság és összehangoltság a partnerrel (12 tétel): a partnerek kapcsolódásának, dinamikus együttmúködésének leírása, személyes és kapcsolati perspektívából.

2. Bevonódás élmény és koncentráció (5 tétel): a tevékenységhez köthető skála, a flow élmény kulcsszempontjainak összefoglalása, a személy elköteleződésének és koncentrációjának leírása, az élmény következményei.

3. Motiváció és pozitív hatás a partnerre (3 tétel): a személy motivációs hatása a partnerre vonatkozóan.

4. Motiváció és tanulás a személy számára (4 tétel): a válaszadó fejlődése a közös tevékenység alatt, amelyet a partnere indukál. 
5. Koordináció a partnerrel a tevékenység során (4 tétel): a partnerek viselkedéses koordinációja a közös tevékenység alatt. A diád tagjainak viselkedéses harmonizációja.

Az FSZK tehát egy olyan multidimenzionális mérőeszköz, amely a flow szinkronizációt, a közös helyzetben tapasztalt flow kísérójelenségeit leíró új konstruktumot kívánja megragadni és mérhetővé tenni. A kérdőívfejlesztési munkálatok során alapvetó a méróeszköz pszichometriai kritériumainak ellenőrzése annak érdekében, hogy megbizonyosodjunk arról, hogy valóban érvényes és megbízhatóan ragadja meg a vizsgálandó konstruktumot (Clark \& Watson, 1995). A kérdőív végleges struktúrájában a fenti öt skála megfelelő reliabilitással bírt, továbbá közepes mértékú együttjárást mutatott a flow élmény feltételeivel és kísérójelenségeivel, alátámasztva ezzel a flow konstruktummal való elvárt mértékú, közepes együttjárást, indokolva a megfelelő kritériumvaliditást (Magyaródi \& Oláh, 2015b).

A jelen vizsgálatot a validitásvizsgálat bővítése indokolja. Szükséges a végleges, 28 tételes FSZK ötfaktoros struktúrájának megerősítése, továbbá annak ellenőrzése, hogy hogyan viszonyulnak a flow szinkronizáció konstruktumát alkotó faktorok a flow élmény konstruktumához, feltételeihez és kísérőjelenségeihez, illetve magának a flow élménynek az átéléséhez. Csikszentmihalyi (1990) érvelése szerint a flow különböző konstruktumok összességét jelenti, amelyet elképzelésünk alapján a flow szinkronizáció kiegészít további dimenziókkal, amely a közös helyzetben végzett tevékenység közben átélt áramlat további kísérőjelenségeit foglalhatja össze, bővítve ezzel az áramlat élmény dinamikus jellemzóinek sorát. A kapcsolódó elméletek alapján a közös célért végzett tevékenység alatt szinkronizációs múködést feltételezünk a résztvevők között (Ackerman \& Bargh, 2010; Bakker, 2005; Bernieri, Davis, Rosenthal, \& Knee, 1994; Campos \& Sternberg, 1981; Dumas, Nadel, Soussignan, Martinerie, \& Garnero, 2010; Hatfield, Cacioppo, \& Rapson, 1994; Schmidt, Morr, Fitzpatrick, \& Richardson, 2012; Trevarthen, 1980), tehát azt a tendenciát, amely szerint a személyek automatikusan másolják, szinkronizálják egymás megnyilvánulásait, akár az átélt élmények vonatkozásában is (Varga \& Józsa, 2013). Mivel a korábbi eredmények alapján tapasztalható egyfajta hozzáadott élmény a közös helyzetben megélt áramlat élmény intenzitásában (Walker, 2010), elképzelhető, hogy az interakciós sajátosságok hatnak egymásra, kibővítve a személy-környezet interakciót az élmény átélése során (Magnusson \& Stattin, 1998; Nowak, Lewenstein, \& Vallacher, 1994).

A flow elmélet (Csikszentmihalyi, 1990), valamint az azt támogató empirikus eredmények szerint az optimális élmény megtapasztalásakor az éntudatosítás, énfókusz elhalványul (Chen, Wigand, \& Nilan, 2000; Pace, 2004; Riva, Waterworth, Waterworth, \& Mantovani, 2011), így célunk annak 
kimutatása, hogy társas helyzetben is igazolható ez az összefüggés, az éntudatosításnak mint állapotjellemzőnek mind a személyes, mind pedig a társas aspektusa (Buss, 1980; Fenigstein, Scheier, \& Buss, 1975) megkülönböztethetó lesz a flow szinkronizáció faktoraitól. Ezáltal kívánjuk megerősíteni, hogy a társas helyzet ellenére, amelyben a társas éntudatosítás állapota aktiválódhatna, mégis inkább elhalványul, mivel áramlat helyzetben kizárólag a tevékenység végzése számít, minden más tényező a figyelmi fókuszon kívül marad, így a flow szinkronizáció faktorai is az áramlat támogatását szolgálják, nem pedig az éntudatosítás különböző aspektusait erősítik. Mivel a szorongás átélése antiflow állapotot jelöl, ahol a készségek nem felelnek meg a helyzet által támasztott kihívásoknak (Massimini \& Delle Fave, 2000), valószínúsíthető, hogy a társas helyzetben, interakció közben átélt flow is fordított viszonyban áll a tapasztalat szorongás mértékével.

Vizsgálatunk célja a flow szinkronizáció konstruktumának minél pontosabb definiálása és mérése volt, a pozitív pszichológia irányelveinek megfelelően (Donaldson, Dollwet, \& Rao, 2015; Kashdan, Steger, \& Steger, Michael, 2011). Ennek keretében célunk volt az FSZK ötfaktoros struktúrájának igazolása, a skálák belső megbízhatóságának, továbbá a skálák konvergens és diszkriminációs érvényességének tesztelése, amelynek során a következő feltételezéseket kívánjuk igazolni, a hipotézisekhez kapcsolt szakirodalmi indoklásokkal megalapozva.

A konvergens validitás teszteléséhez kapcsolódó hipotézisek alapján a flow szinkronizáció faktorai:

1. A flow állapot feltételeit és kísérójelenségeit leíró faktorokkal pozitív irányú, közepes erősségú együttjárást mutatnak (Magyaródi \& Oláh, $2015 b)$. Az FSZK bevonódás élmény és koncentráció faktora feltételezhetően erős együttjárást mutat az élménnyel való egybeolvadást, a flow dinamikáját leíró skálával.

2. A diádikus interakció szubjektív élményét leíró intimitás, összhang és játékosság skálákkal pozitív irányú, közepes erősségú együttjárást mutatnak (Varga, Józsa, \& Urbán, 2002). Mivel a flow szinkronizáció a közös feladatmegoldás alatti interakció sajátosságait is tartalmazza (Varga, Józsa, Bányai, \& Gősi-Greguss, 2012), várható, hogy az összhang faktor erős összefüggést mutat a flow szinkronizáció faktoraival, leginkább a hatékonyság és összehangoltság a partnerrel, valamint a koordináció a partnerrel skálák tekintetében. A játékosság faktor továbbá a flow szinkronizáció flowt leíró bevonódás élmény és koncentráció faktorával mutathat erősebb együttjárást, a flow élmény bühleri funkcióörömhöz, a játékkal történő motivációs aspektusához kapcsolódva (Engeser \& Schiepe-Tiska, 2012).

3. Az állapotszintú kíváncsiság tényezőjével pozitív irányú, közepes erősségú együttjárást mutat. A kíváncsiság pillanatnyi állapotként a 
személy a környezeti ingerek iránt fokozottabban érdeklődik, megközelítő viselkedéssel jár együtt (Oláh, 2005). Az érdeklődés (Bakker, 2005), a kíváncsiság (Montgomery, Sharafi, \& Hedman, 2004) a flow élménnyel együttjáró állapotoknak tekinthető, amely a közös élmény és feladat megoldása során is megjelenhet, az áramlathoz kapcsolódó személy-környezet interakció (Nakamura \& Csikszentmihalyi, 2002) másik személy által történő bővülésével növelheti a kihívás szintet, és motiválóan hathat a készségek fejlesztésére is, amely a feladat iránti kíváncsiságot, érdeklődési szintet növelheti.

A diszkriminációs validitás teszteléséhez kapcsolódó hipotézisek alapján a flow szinkronizáció faktorai:

1. A személyes és társas éntudatosítás állapotával negatív irányú, gyenge együttjárást mutatnak. Az éntudatosítás a figyelem fókuszálását jelenti a személy egyéni (személyes éntudatosítás) vagy társas aspektusaira (társas éntudatosítás) (Fenigstein és mtsai, 1975). Mivel flow élmény átélésekor a figyelem fókusza a végzett tevékenységre korlátozódik (Csikszentmihalyi, 1990), így gyenge összefüggés várható az éntudatosítás és a flow szinkronizáció faktorai között, amelyek a tevékenységbe való bevonódást segíthetik az interakció során, nem pedig az énfókusz különböző tartományaira való koncentrációt.

2. A feszültséggel mérsékelt, negatív irányú együttjárást mutat. A feszültség átélése az interakció gördülékenységét gátolja (Varga \& Józsa, 2013), ezért feltételezhetó a flow szinkronizációs faktorokkal való ellentétes irányú kapcsolata.

3. A szorongás faktoraival negatív előjelú, gyenge együttjárást mutatnak. A szorongás olyan komplex érzelmi reakció, amely során fenyegetó ingereket észlel a személy a környezetében (Oláh, 2005), és szintén a figyelem magas fokú koncentrációjával jár együtt (Engeser \& SchiepeTiska, 2012), akárcsak a flow élmény, azonban a szorongás antiflow élménynek tekinthető (Massimini \& Carli, 1988), a kihívás készségekhez képesti túl magas szintje miatt, így megakadályozza azt, hogy a közös interakcióba bevonódva a cél megoldásán dolgozzon a személy.

4. A társas szorongással negatív előjelú, gyenge együttjárást mutat. Mivel a társas szorongás magas szintje együttjár az éntudatosítás megnövekedett szintjével, és az interakciók kerülésének tendenciájával (Brown, Silvia, Myin-Germeys, \& Kwapil, 2007), feltételezzük, hogy gyenge kapcsolatban van a flow szinkronizáció faktoraival, amely a közös interakció során átélt flow élményt támogató interakciós és áramlat élménnyel összefüggő sajátosságokat foglalja össze.

5. A düh állapotával negatív irányú, gyenge együttjárást mutatnak. A düh átmeneti érzelmi állapotot jelöl, amely intenzitását tekintve a 
bosszankodás és dühöngés érzése között mozoghat (Oláh, 2005). Elkerülő viselkedést vált ki az interakciós partnerből, félelemkeltó lehet (Ackerman \& Bargh, 2010), így az interakció felbomolhat, amely a flow élmény társas helyzetben való megélését és az interakciós támogató tényezőket veszélyeztetheti. A düh ugyanakkor támogatja a feladatra való fókuszálást az akadályozó tényezők figyelmen kívül hagyása útján (Oláh, 2005), ezért az állapot szorongáshoz képest kisebb mértékú negatív együttjárás prognosztizálható a flow mért tényezői és a düh élmény aktuális szintje között.

\section{Módszer}

\subsection{Vizsgálati személyek és eljárás}

A keresztmetszeti kérdőíves vizsgálat online felület segítségével került lebonyolításra. A kényelmi mintavétel során hólabda módszert alkalmaztunk. A válaszadók a kutatási tájékoztató elolvasása után döntöttek a vizsgálati részvételben való beleegyezésról. A részvétel önkéntes és anonim volt, és nem járt semmilyen kompenzációval. A kérdőívcsomag kitöltése megközelítőleg 20 percet vett igénybe. Az FSZK validitásának vizsgálatát az ELTE PPK Kutatásetikai Bizottsága jóváhagyta (Iktatási szám: 2015/130.).

A kutatásban 367 felnőtt (18 éven felüli) személy, 119 férfi és 248 nő vett részt. A válaszadók átlagéletkora 28,5 év volt $(S D=12,89$ év). A minta sajátosságait a 1. táblázat részletezi.

1. táblázat. A résztvevők ( $\mathrm{n}=367)$ százalékos eloszlása a demográfiai sajátosságok mentén

\begin{tabular}{|l|l|c|}
\hline \multirow{2}{*}{ Lakóhely } & Gyakoriság (\%) \\
\hline \multirow{5}{*}{ Családi állapot } & Budapest & 45,5 \\
\cline { 2 - 3 } & Vidéki nagyváros & 23,2 \\
\cline { 2 - 3 } & Vidéki kisváros, falu & 26,4 \\
\cline { 2 - 3 } & Külföld & 4,9 \\
\hline \multirow{3}{*}{ Iskolai végzettség } & Egyedülálló & 42,5 \\
\cline { 2 - 3 } & Párkapcsolatban & 57,5 \\
\hline & Alapfokú végzettség & 2,2 \\
\cline { 2 - 3 } & Középfokú végzettség & 63,2 \\
\cline { 2 - 3 } & Felsőfokú végzettség & 34,6 \\
\hline
\end{tabular}




\subsection{Mérőeszközök}

A válaszadók által kitöltött online kérdőívcsomag a demográfiai kérdések (nem, életkor, iskolai végzettség, családi állapot, lakóhely) után a következő mérőeszközökből állt.

Általános Flow Leírás Társas Interakciókban (Magyaródi \& Oláh, 2015a). A válaszadó egy leírást olvashat a társas helyeztben átélhetó flow élményról, amely után ötfokú Likert-típusú skálán (végpontok: egyáltalán nem [1], egészen nagymértékben [5]) értékeli, hogy milyen gyakran, milyen intenzíven tapasztalja meg az adott élményt. A leírás segítségével azonosítható az a legjellemzóbb tevékenység is, amely során az élményt tapasztalja a személy. A flow élményhez kapcsolódó múltbéli tevékenység felidéztetése a vizsgálati személlyel gyakori módszernek számít a flow élmény vizsgálatakor (Tenenbaum, Fogarty, \& Jackson, 1999), így a jelen kutatásban a mérőeszközt a leggyakrabban felidézett, közös, együttmúködő tevékenység során tapasztalt flow helyzet retrospektív értékelése céljából alkalmaztuk.

Az összes alkalmazott méróeszköz a felidézett áramlat élménnyel kísért közös együttmúködés során tapasztalt tevékenységre vonatkozik, állapotjellemző́ként ragadva meg a vizsgált konstruktumokat.

Flow Szinkronizáció Kérdőív (FSZK; Magyaródi \& Oláh, 2015b). A 28 tételes kérdőív 5 skálán keresztül ragadja meg azokat a tényezóket, amelyek a közös interakciós flow helyzetben az átélt élményt kísérik, támogatják. A skálák a következők: Hatékonyság és összehangoltság a partnerrel; Bevonódás élmény és koncentráció; Motiváció és pozitív hatás a partnerre; Motiváció és tanulás a személy számára; Koordináció a partnerrel a tevékenység közben. A válaszadás ötfokú Likert-típusú skálán történik az egyáltalán nem (1) és a teljes mértékben (5) végpontok között. A skálákon elért magasabb pontszám a flow szinkronizációs összetevők intenzívebb megtapasztalását jelzi. A skálák belső megbízhatósága megfelelő (Cronbach- $a=$ 0,80-0,93).

Flow Állapot Kérdőí (FÁK; Magyaródi, Nagy, Soltész, Mózes, \& Oláh, 2013). A FÁK az áramlat élmény alapdimenzióit méri, 20 itemen keresztül. A résztvevők ötfokú Likert-típusú skálán értékelik az egyes állításokat (végpontok: egyáltalán nem értek egyet [1], teljesen egyetértek [5]). A FÁK két alskálából áll: a Kihívás-készség egyensúly skálából, amely a flow zónába lépés alapvető feltételeire utal, az Egybeolvadás az élménnyel skála pedig a flow kísérójelenségeit foglalja össze. A skálákon elért magasabb pontszám a flow élmény feltételeinek magasabb szintú kidolgozottságát, az élmény emelkedettebb intenzitását jelzi. A skálák belső megbízhatósága megfelelő (Cronbach- $\alpha=0,91-0,92$ ). 
Diádikus Interakció Harmónia Kérdőív (DIH; Varga és mtsai, 2002). A DIH azt méri fel, hogy a diádikus interakció résztvevői hogyan ítélik meg az együttlétüket. A kérdőív 50 tételt tartalmaz, amelyeket önbeszámolós módon ítélnek meg a vizsgálati személyek, ötfokú Likert-típusú skálán értékelve, hogy mennyire jellemezte az adott tételben megfogalmazott állítás azt a kétszemélyes interakciót, amelyben részt vett a személy (végpontok: egyáltalán nem [1], teljes mértékben [5]). A kérdőív három pozitív skálát (Intimitás, Összhang, Játékosság) és egy negatív skálát (Feszültség) tartalmaz. A skálákon elért magasabb pontszám a partnerrel való együttmúködés közben tapasztalt nagyobb mértékú intimitást, összhangot és játékosságot, illetve feszültséget jelez. A skálák belső konzisztenciája megfelelő (Cronbach-a $=0,78-0,86$ ).

Állapot-Vonás Személyiség Kérdőív: Állapotszorongás kérdőív (State-Trait Personality Inventory; STPI; Spielberger, Gorsuch, Lushene, Vagg, \& Jacobs, 1983). A kérdőív magyar nyelvú adaptálása Oláh Attila nevéhez köthető (Oláh, 1987). A kérdőív 30 tételből áll, és három skála (Szorongás; Düh; Kíváncsiság) segítségével ragadja meg az állapotszorongás mértékét. A jelen vizsgálatban a kérdóív állapot verzióját alkalmaztuk, a 3 vizsgált skála: Szorongás mint pillanatnyi állapot; Düh mint pillanatnyi állapot; Kíváncsiság mint pillanatnyi állapot. A kérdőív tételeit négyfokú Likert-típusú skálán kell értékelni (végpontok: egyáltalán nem [1], nagyon [4]). A skálákon elért magasabb pontszám a végzett tevékenység során tapasztalt magasabb szintú szorongást, dühöt és kíváncsiságot jelez. A skálák belső konzisztenciája megfelelőnek bizonyult (Oláh, 2005) (állapotszorongás skála: Cronbach- $a_{\text {nók }}=0,86$; Cronbach- $a_{\text {férfiak }}=0,84$; kíváncsiság skála: Cronbach- $a_{\text {nók }}=0,66$; Cronbach$a_{\text {férfiak }}=0,74$; düh skála: Cronbach- $a_{\text {nók }}=0,79 ;$ Cronbach- $a_{\text {férfiak }}=0,87$ ).

Éntudatosság Kérdöív (Self-Consciousness Scale; SCS; Fenigstein és mtsai, 1975). A kérdőív az éntudatosítás különböző aspektusait vizsgálja: személyes és társas éntudatosítás, társas szorongás. A kérdőív magyar verzióját Rózsa Sándor és munkatársai (Rózsa, Reinhardt, \& Kulcsár, 2006) alkották meg. A 23 tételt ötfokú Likert-típusú skálán kell értékelni (végpontok: egyáltalán nem jellemző [1], nagyon jellemző [5]). A skálákon elért magasabb pontszám nagyobb mértékú személyes és társas éntudatosságot, illetve társas szorongást jelez a végzett tevékenység során. Az eredeti méróeszköz (Fenigstein és mtsai, 1975) skáláinak teszt-reteszt reliabilitása megfelelő volt (társas éntudatosítás skála: $\mathrm{r}=0,84$; személyes éntudatosítás skála: $\mathrm{r}=0,79$; társas szorongás skála: $\mathrm{r}=0,73$ ). A skálák belső konzisztenciája a magyar nyelvú adaptáció alapján szintén elfogadhatónak bizonyult (pontos, közölt adat csak a személyes éntudatosítás skálához áll rendelkezésre: Cronbach- $\alpha=0,75$; Rózsa és mtsai, 2006). 


\subsection{Statisztikai elemzések}

A skálák belső konzisztenciájának becsléséhez Cronbach-a értéket számítottunk. A változók normalitásának ellenőrzésére a statisztikai hiba csökkentése érdekében a legpontosabb eljárásként javasolt Shapiro-Wilk-próbát (Ghasemi \& Zahediasl, 2012) alkalmaztuk. Az FSZK ötfaktoros struktúrájának ellenőrzéséhez konfirmatív faktorelemzést végeztünk. A lineáris kapcsolatokat Spearman-féle rangkorrelációs eljárással vizsgáltuk. Az elemzések nagy számára való tekintettel Bonferroni-korrekciót alkalmaztunk az elsőfajú hiba valószínúségének csökkentése érdekében. Az elemzéseket az IBM SPSS Statistics 23.0 és az IBM SPSS AMOS 23.0 szoftverek segítségével végeztük.

\section{Eredmények}

\subsection{A vizsgálat alapstatisztikája}

A Flow Szinkronizáció Kérdőív, valamint a validitásvizsgálatba bevont skálák belső megbízhatósági mutatói a jelen vizsgálat során megfelelőnek bizonyultak, amely eredmények a 2. táblázatban kerülnek ismertetésre a leíró statisztikai értékek mellett.

2. táblázat. A Flow Szinkronizáció Kérdőív validitásvizsgálatában alkalmazott skálák leíró statisztikája és belsó megbízhatósága

\begin{tabular}{|l|r|r|c|c|c|}
\hline \multicolumn{1}{|c|}{ Skála } & $\begin{array}{r}\text { Átlag } \\
\text { (szórás) }\end{array}$ & $\begin{array}{r}\text { Cronbach-a } \\
\text { (tételszám) }\end{array}$ & W & df & p \\
\hline $\begin{array}{l}\text { Hatékonyság és összehangoltság a } \\
\text { partnerrel (FSZK) }\end{array}$ & $\begin{array}{r}4,32 \\
(0,57)\end{array}$ & $\begin{array}{r}0,93 \\
(12)\end{array}$ & 0,89 & 367 & $<0,001$ \\
\hline $\begin{array}{l}\text { Bevonódás élmény és koncentráció } \\
\text { (FSZK) }\end{array}$ & $\begin{array}{r}3,93 \\
(0,79)\end{array}$ & $\begin{array}{r}0,82 \\
(5)\end{array}$ & 0,95 & 367 & $<0,001$ \\
\hline $\begin{array}{l}\text { Motiváció és pozitív hatás a partnerre } \\
\text { (FSZK) }\end{array}$ & $\begin{array}{r}4,21 \\
(0,64)\end{array}$ & $\begin{array}{r}0,78 \\
(3)\end{array}$ & 0,89 & 367 & $<0,001$ \\
\hline $\begin{array}{l}\text { Motiváció és tanulás a személy számára } \\
\text { (FSZK) }\end{array}$ & $\begin{array}{r}4,11 \\
(0,67)\end{array}$ & $\begin{array}{r}0,77 \\
(4)\end{array}$ & 0,90 & 367 & $<0,001$ \\
\hline $\begin{array}{l}\text { Koordináció a partnerrel a tevékenység } \\
\text { közben (FSZK) }\end{array}$ & $\begin{array}{r}3,61 \\
(0,76)\end{array}$ & $\begin{array}{r}0,72 \\
(4)\end{array}$ & 0,97 & 367 & $<0,001$ \\
\hline Kihívás-készség egyensúly (FÁK) & $\begin{array}{r}3,84 \\
(0,52)\end{array}$ & $\begin{array}{r}0,85 \\
(11)\end{array}$ & 0,95 & 367 & $<0,001$ \\
\hline
\end{tabular}




\begin{tabular}{|c|c|c|c|c|c|}
\hline Skála & $\begin{array}{l}\text { Átlag } \\
\text { (szórás) }\end{array}$ & $\begin{array}{l}\text { Cronbach-a } \\
\text { (tételszám) }\end{array}$ & $\mathbf{W}$ & $\mathrm{df}$ & $p$ \\
\hline Egybeolvadás az élménnyel (FÁK) & $\begin{array}{r}4,10 \\
(0,59)\end{array}$ & $\begin{array}{r}0,84 \\
(9)\end{array}$ & 0,94 & 367 & $<0,001$ \\
\hline Intimitás (DIH) & $\begin{array}{r}2,89 \\
(1,26)\end{array}$ & $\begin{array}{l}0,94 \\
(10)\end{array}$ & 0,95 & 367 & $<0,001$ \\
\hline Összhang (DIH) & $\begin{array}{r}4,19 \\
(0,67)\end{array}$ & $\begin{array}{l}0,92 \\
(10)\end{array}$ & 0,90 & 367 & $<0,001$ \\
\hline Játékosság (DIH) & $\begin{array}{r}3,93 \\
(0,76)\end{array}$ & $\begin{array}{r}0,83 \\
(6)\end{array}$ & 0,93 & 367 & $<0,001$ \\
\hline Feszültség (DIH) & $\begin{array}{r}2,22 \\
(0,49)\end{array}$ & $\begin{array}{r}0,78 \\
(7)\end{array}$ & 0,92 & 367 & $<0,001$ \\
\hline $\begin{array}{l}\text { Szorongás mint pillanatnyi állapot } \\
\text { (STPI) }\end{array}$ & $\begin{array}{r}1,99 \\
(0,31)\end{array}$ & $\begin{array}{l}0,82 \\
(10)\end{array}$ & 0,92 & 367 & $<0,001$ \\
\hline Düh mint pillanatnyi állapot (STPI) & $\begin{array}{r}1,25 \\
(0,44)\end{array}$ & $\begin{array}{l}0,89 \\
(10)\end{array}$ & 0,62 & 367 & $<0,001$ \\
\hline $\begin{array}{l}\text { Kíváncsiság mint pillanatnyi állapot } \\
\text { (STPI) }\end{array}$ & $\begin{array}{r}2,57 \\
(0,46)\end{array}$ & $\begin{array}{l}0,75 \\
(10)\end{array}$ & 0,99 & 367 & $<0,001$ \\
\hline Személyes éntudatosítás (SCS) & $\begin{array}{r}3,21 \\
(0,64)\end{array}$ & $\begin{array}{l}0,81 \\
(10)\end{array}$ & 0,99 & 367 & 0,017 \\
\hline Társas éntudatosítás (SCS) & $\begin{array}{r}3,79 \\
(0,68)\end{array}$ & $\begin{array}{r}0,78 \\
(7)\end{array}$ & 0,96 & 367 & $<0,001$ \\
\hline Társas szorongás (SCS) & $\begin{array}{r}2,88 \\
(0,75)\end{array}$ & $\begin{array}{r}0,80 \\
(6)\end{array}$ & 0,99 & 367 & 0,028 \\
\hline
\end{tabular}

Megjegyzés. FSZK: Flow Szinkronizáció Kérdőív, FÁK: Flow Állapot Kérdőív,

DIH: Diádikus Interakció Harmónia Kérdőív, STPI: Állapot-Vonás Személyiség Kérdőív, SCS: Éntudatosság Kérdőív. W = Shapiro-Wilk teszt.

\subsection{A Flow Szinkronizáció Kérdőív faktorelemzése}

A mérete alapján a minta alkalmas volt a konfirmatív faktoranalízis elvégzésére (Wolf, Harrington, Clark, \& Miller, 2013), ezért megerősítő faktorelemzéssel vizsgáltuk az FSZK korábban azonosított ötfaktoros struktúráját (Magyaródi \& Oláh, 2015b). Az illeszkedési mutatók nem bizonyultak elfogadhatónak $\left(\chi^{2}(340)=1121,93, p<0,001 ; \mathrm{CMIN} / \mathrm{df}=3,30 ; \mathrm{TLI}=0,851 ; \mathrm{CFI}\right.$ = 0,866; RMSEA = 0,079), ezért a modifikációs indexek segítségével addig módosítottuk a modellt, azaz szabadítottuk fel a kovarianciákat (lásd 3. táblázat), míg egy elfogadható illeszkedésú változatához jutottunk $\left(\chi^{2}(336)=\right.$ 
857,27, $\mathrm{p}<0,001 ; \mathrm{CMIN} / \mathrm{df}=2,55$, TLI $=0,900, \mathrm{CFI}=0,9311, \mathrm{RMSEA}=$ 0,065). A modell illeszkedését az egy skálába tartozó tételek közötti kovarianciák felszabadítása javította, az összefüggő tételek ugyanazon tartalomra kérdeznek rá (2. modell: partnerrel való összehangoltság, 3. modell: partner motivációs hatása, 4. modell: flow élmény következményei, feltöltöttség, 5. modell: partnerrel való kölcsönös kapcsolat). Az ötfaktoros megoldást így elfogadhatónak, érvényesnek tekintjük.

3. táblázat. Az FSZK ötfaktoros modelljének illeszkedési mutatói, a modifikációs indexek alapján történő változtatások után

\begin{tabular}{|l|c|c|c|c|c|}
\hline \multicolumn{1}{|c|}{ Modellek } & \multicolumn{1}{|c|}{$\boldsymbol{x}^{2}$ (df) } & CMIN/df & TLI & CFI & RMSEA \\
\hline Eredeti, ötfaktoros megoldás & $1121,93^{* * *}(340)$ & 3,30 & 0,851 & 0,866 & 0,079 \\
\hline $\begin{array}{l}\text { 18. tétel és 12. tétel hibatagjai } \\
\text { (1. faktor) }\end{array}$ & $1012,12^{* * *}(339)$ & 2,99 & 0,871 & 0,885 & 0,076 \\
\hline $\begin{array}{l}\text { 7. tétel és 25. tétel hibatagjai } \\
\text { (4. faktor) }\end{array}$ & $946,33^{* * *}(338)$ & 2,80 & 0,883 & 0,896 & 0,070 \\
\hline $\begin{array}{l}\text { 2. tétel és 24. tétel hibatagjai } \\
\text { (2. faktor) }\end{array}$ & $882,94^{* * *}(337)$ & 2,62 & 0,895 & 0,906 & 0,067 \\
\hline $\begin{array}{l}\text { 6. tétel és 4. tétel hibatagjai } \\
\text { (1. faktor) }\end{array}$ & $857,27^{* * *}(336)$ & 2,55 & 0,900 & 0,911 & 0,065 \\
\hline
\end{tabular}

Megjegyzés. $\chi^{2}(d f)=$ a khi-négyzet próba eredménye a szabadságfokkal,

*** $\mathrm{p}<0,001, \mathrm{CMIN} / \mathrm{df}=$ khi-négyzet és szabadságfok hányadosa, TLI = Tucker-LewisIndex, CFI = Komparatív illeszkedési mutató, RMSEA = a becslés standard hibája.

Az FSZK skáláinak lineáris kapcsolatát Spearman-féle rangkorrelációs elemzéssel teszteltük, Bonferroni-korrekció alkalmazásával ( $p<0,05 / 10=0,005)$. Eredményeink szerint a Flow Szinkronizáció Kérdőív skálái között pozitív irányú, közepes erősségú, illetve erős együttjárás található (4. táblázat).

4. táblázat. A Flow Szinkronizáció Kérdőív skáláinak interkorrelációja (Spearman-féle rangkorrelációs együtthatók)

\begin{tabular}{|l|c|c|c|c|c|}
\hline \multicolumn{1}{|c|}{ A Flow Szinkronizáció Kérdooív skálái } & $\mathbf{1 .}$ & $\mathbf{2}$ & $\mathbf{3 .}$ & $\mathbf{4 .}$ & $\mathbf{5 .}$ \\
\hline 1. Hatékonyság és összehangoltság a partnerrel & - & & & & \\
\hline 2. Élmény és koncentráció & $0,60^{*}$ & - & & & \\
\hline 3. Motiváció és pozitív hatás a partnerre & $0,71^{*}$ & $0,47^{*}$ & - & & \\
\hline 4. Motiváció és tanulás a személy számára & $0,63^{*}$ & $0,47^{*}$ & $0,50^{*}$ & - & \\
\hline 5. Koordináció a partnerrel a tevékenység közben & $0,72^{*}$ & $0,56^{*}$ & $0,51^{*}$ & $0,54^{*}$ & - \\
\hline
\end{tabular}

Megjegyzés. * $\mathrm{p}<0,005$. 


\subsection{A Flow Szinkronizáció Kérdőív validitásvizsgálata}

Az FSZK konstruktum validitásának teszteléséhez szintén Spearman-féle rangkorrelációs vizsgálatot végeztünk. A nagyszámú korrelációs elemzés futtatása miatt Bonferroni-korrekciót alkalmazunk ( $<<0,05 / 30=0,002)$. Eredményeink szerint a flow szinkronizáció összetevói a flow élmény feltételeivel jellemzően közepes erősségú, pozitív irányú együttjárást mutatnak, ami alátámasztja a kérdőív kritériumvaliditását. Az intimitás, összhang és játékosság közepes erősségú, illetve erős, pozitív irányú együttjárást mutatnak a flow szinkronizáció aspektusaival. Az összhang és a hatékonyság és összehangoltság a partnerrel tényezők közötti együttjárás magasnak bizonyult, amit a hasonló tartalom indokol. Az állapotszintú kíváncsiság ugyancsak a várt, pozitív irányú, közepes erősségú együttjárást mutatja a flow szinkronizáció komponensekkel. A konvergens validitás mutatóit bemutató korrelációs mátrix az 5. táblázatban található.

5. táblázat. A Flow Szinkronizáció Kérdőív konvergens validitásának tesztelése korrelációs eljárással (Spearman-féle rangkorrelációs együtthatók)

\begin{tabular}{|l|c|c|c|c|c|}
\hline \multicolumn{1}{|c|}{ Változók } & \multicolumn{5}{|c|}{ A Flow Szinkronizáció Kérdóív skálái } \\
\cline { 2 - 6 } & $\begin{array}{c}\text { Hatékonyság } \\
\text { és össze- } \\
\text { hangoltság } \\
\text { a partnerrel }\end{array}$ & $\begin{array}{c}\text { Élmény } \\
\text { és } \\
\text { koncent- } \\
\text { ráció }\end{array}$ & $\begin{array}{c}\text { Motiváció } \\
\text { és pozitív } \\
\text { hatás } \\
\text { a partnerre }\end{array}$ & $\begin{array}{c}\text { Motiváció } \\
\text { és tanulás } \\
\text { a személy } \\
\text { számára }\end{array}$ & $\begin{array}{c}\text { Koordináció } \\
\text { a partnerrel } \\
\text { a tevékeny- } \\
\text { ség közben }\end{array}$ \\
\hline $\begin{array}{l}\text { Kihívás- } \\
\text { készség } \\
\text { egyensúly } \\
\text { (FÂK) }\end{array}$ & $0,46^{*}$ & $0,42^{*}$ & $0,45^{*}$ & $0,16^{*}$ & $0,33^{*}$ \\
\hline $\begin{array}{l}\text { Egybeolvadás } \\
\text { az élménnyel } \\
\text { (FÁK) }\end{array}$ & $0,49^{*}$ & $0,62^{*}$ & $0,38^{*}$ & $0,36^{*}$ & $0,41^{*}$ \\
\hline $\begin{array}{l}\text { Intimitás } \\
\text { (DIH) }\end{array}$ & $0,42^{*}$ & $0,42^{*}$ & $0,36^{*}$ & $0,30^{*}$ & $0,48^{*}$ \\
\hline $\begin{array}{l}\text { Összhang } \\
\text { (DIH) }\end{array}$ & $0,78^{*}$ & $0,58^{*}$ & $0,55^{*}$ & $0,50^{*}$ & $0,63^{*}$ \\
\hline $\begin{array}{l}\text { Játékosság } \\
\text { (DIH) }\end{array}$ & $0,64^{*}$ & $0,59^{*}$ & $0,46^{*}$ & $0,47^{*}$ & $0,55^{*}$ \\
\hline $\begin{array}{l}\text { Kíváncsiság } \\
\text { mint } \\
\text { pillanatnyi } \\
\text { állapot (STPI) }\end{array}$ & $0,41^{*}$ & $0,39^{*}$ & $0,40^{*}$ & $0,36^{*}$ & $0,39^{*}$ \\
\hline
\end{tabular}

Megjegyzés: FÁK: Flow Állapot Kérdőív, DIH: Diádikus Interakció Harmónia Kérdőív, STPI: Állapot-Vonás Személyiség Kérdőív. * p < 0,002. 
A Flow Szinkronizáció Kérdőív diszkriminációs érvényességének tesztelése érdekében szintén Spearman-féle rangkorrelációs elemzést végeztünk. A nagyszámú korrelációs elemzés futtatása miatt ezúttal is Bonferronikorrekciót alkalmazunk ( $p<0,05 / 30=0,002)$. Eredményeink szerint a feszültség, a szorongás, a társas szorongás, valamint a düh gyenge és mérsékelt, fordított irányú együttjárást mutatnak a flow szinkronizáció komponenseivel. Az éntudatosítás személyes aspektusa egy esetben sem mutatott szignifikáns kapcsolatot a flow szinkronizáció komponenseivel. A társas éntudatosítás pedig bár többnyire szignifikáns, ám csak rendkívül gyenge, negatív irányú együttjárást mutat a flow szinkronizációval. Mindez alátámasztja az FSZK diszkriminációs validitását. Az eredményeket a 6. táblázatban mutatjuk be részletesen.

6. táblázat. A Flow Szinkronizáció Kérdőív diszkriminációs validitásának tesztelése korrelációs eljárással (Spearman-féle rangkorrelációs együtthatók)

\begin{tabular}{|l|c|c|c|c|c|}
\hline \multirow{1}{*}{ Változók } & \multicolumn{5}{|c|}{ A Flow Szinkronizáció Kérdőív skálái } \\
\cline { 2 - 6 } & $\begin{array}{c}\text { Hatékonyság } \\
\text { és össze- } \\
\text { hangoltság } \\
\text { a partnerrel }\end{array}$ & $\begin{array}{c}\text { Élmény } \\
\text { és } \\
\text { koncent- } \\
\text { ráció }\end{array}$ & $\begin{array}{c}\text { Motiváció } \\
\text { és pozitív } \\
\text { hatás a } \\
\text { partnerre }\end{array}$ & $\begin{array}{c}\text { Motiváció } \\
\text { és tanulás } \\
\text { a személy } \\
\text { számára }\end{array}$ & $\begin{array}{c}\text { Koordináció } \\
\text { a partnerrel } \\
\text { a tevékeny- } \\
\text { ség közben }\end{array}$ \\
\hline Feszültség (DIH) & $-0,51^{*}$ & $-0,45^{*}$ & $-0,40^{*}$ & $-0,21^{*}$ & $-0,34^{*}$ \\
\hline $\begin{array}{l}\text { Szorongás mint } \\
\text { pillanatnyi } \\
\text { állapot (STPI) }\end{array}$ & $-0,45^{*}$ & $-0,52^{*}$ & $-0,37^{*}$ & $-0,16^{*}$ & $-0,29^{*}$ \\
\hline $\begin{array}{l}\text { Düh mint } \\
\text { pillanatnyi } \\
\text { állapot (STPI) }\end{array}$ & $-0,32^{*}$ & $-0,27^{*}$ & $-0,24^{*}$ & $-0,18^{*}$ & $-0,17^{*}$ \\
\hline $\begin{array}{l}\text { Személyes } \\
\text { éntudatosítás } \\
\text { (SCS) }\end{array}$ & 0,05 & 0,06 & 0,10 & 0,13 & 0,13 \\
\hline $\begin{array}{l}\text { Társas } \\
\text { éntudatosítás } \\
\text { (SCS) }\end{array}$ & $0,19^{* *}$ & $0,12^{*}$ & $0,19^{*}$ & $0,16^{*}$ & 0,12 \\
\hline $\begin{array}{l}\text { Társas szorongás } \\
\text { (SCS) }\end{array}$ & $-0,16^{*}$ & $-0,15$ & $-0,21^{*}$ & $-0,03$ & $-0,09$ \\
\hline
\end{tabular}

Megjegyzés: DIH: Diádikus Interakció Harmónia Kérdőív, STPI: Állapot-Vonás Személyiség Kérdőív, SCS: Éntudatosság Kérdőív.* p < 0,002. 


\section{Diszkusszió}

A vizsgálat célja a Flow Szinkronizáció Kérdőív (FSZK; Magyaródi \& Oláh, 2015b) pszichometriai jellemzőinek, faktorstruktúrájának, megbízhatóságának, továbbá konvergens és diszkriminációs érvényességének tesztelése volt. Az eredmények alapján elmondható, hogy a kérdőív faktorstruktúrája alátámasztást nyert, a skálái megfelelő belső konzisztenciával rendelkeznek, továbbá a validitásvizsgálat során megfogalmazott hipotéziseink nagyrészt beigazolódtak, mert a várt erősségú és irányú együttjárásokat kaptuk a korrelációs elemzések eredményeként.

A megerősítő faktorelemzés igazolta a flow szinkronizáció konstruktum multidimenzionalitását, az áramlat konstruktumához hasonlóan (Csikszentmihalyi, 1990). Az elemzés alátámasztotta az FSZK ötfaktoros struktúráját. Mivel azonban a flow szinkronizáció egy új konstruktumot jelöl a pozitív pszichológiában, elképzelhetőnek tartjuk, hogy a további kutatások bóvíteni fogják a dimenzióinak számát.

Feltételezésünk szerint az FSZK faktorai a flow élmény feltételeit és élménykomponenseit operacionalizáló mérőeszköz (FÁK; Magyaródi és mtsai, 2013) skáláival jellemzően közepes mértékú összefüggést kapunk. A flow élmény feltételei a vártnak megfelelően, közepes mértékben járnak együtt a hatékonyság észlelésével, az átélt élmény minőségével, a partnerre motivációs tényezőkkel és koordinációs faktorokkal egyaránt. Amennyiben a feladathelyzetben résztvevő személyek számára a feladat kihívást jelent, világos célkitúzést tartalmaz, és mindeközben az együttmúködési helyzet által támogatott flow szinkronizációs tényezőket tapasztalják, akkor lehetőség van arra, hogy az optimális élmény (Nakamura \& Csikszentmihalyi, 2002) minősége fokozódjon. A Flow Állapot Kérdőív (Magyaródi és mtsai 2013) Egybeolvadás az élménnyel faktora, amely a flow élmény kísérőjelenségeit foglalja össze, szintén az elvárt közepes együttjárást mutatja a flow szinkronizáció tényezőivel. Megjegyzendő, hogy erős együttjárás tapasztalható az FSZK Bevonódás élmény és koncentráció faktorával, amely kiemelten a társas helyzet során átélt áramlat élmény sajátosságait (Csikszentmihalyi, 1990; Nakamura \& Csikszentmihalyi, 2002) foglalja össze. Mivel mindkét faktor az optimális élmény minőségét leíró jellemző́ket foglalja össze, így elfogadható a két konstruktum nagymértékú közös varianciája. A Diádikus Interakció Harmónia Kérdőív (Varga \& Józsa, 2013) az interakcióban résztvevő személyek közötti kölcsönhatás minőségét vizsgálja, így a feladathelyzetben való együttmúködés interakciós aspektusát emeli ki leginkább. A jelen vizsgálatban közös feladat megoldásának élménykomponenseit vizsgáltuk, így az elvártak alapján az intimitás faktor közepes mértékú együttjárást mutat a flow szinkronizációs faktorokkal. Az összhang és játékosság a hipotézisünknek megfelelően rendkívül szoros összefüggést mutat az FSZK ha- 
tékonyság és összehangoltság skálájával. Az összhang skála a partneri kapcsolat minőségére utal, amely akár egy következő közös élményszerzés (Mérei, 1947), akár az énkiterjesztés (Aron \& Aron, 1996) lehetőségét is tartalmazza, a közös feladathelyzetben átélt flow élményen keresztül (Graham, 2008), amely a játékosság faktorhoz való kapcsolódást is indokolhatja.

A közös feladathelyzetben tapasztalt kíváncsiság mértéke az elvártak szerint közepes mértékben függött össze a flow szinkronizáció faktoraival. A kíváncsiság megközelítő viselkedést takar, arra az intenzív vágyra utal, amely az explorációra, újdonságok keresésére és megértésére ösztönzi a személyt (Hilsenroth, Segal, \& Hersen, 2003). A megközelítő viselkedés támogathatja a partnerrel való hatékonyságot, a feladatmegoldás során tapasztalható flow élményt (Oláh, 2005), a partnerrel és a konkrét feladattal szembeni nyitottságot (Collins, Litman, \& Spielberger, 2004), amelyek a flow élmény átélése során a személy-környezet interakciót meghatározzák (Magnusson \& Stattin, 1998; Nakamura \& Csikszentmihalyi, 2002), tehát a flow szinkronizációs faktorok múködését facilitálhatja a kíváncsiság megélése.

A diszkriminációs validitás teszteléséhez külső kritériumként a feszültség, szorongás, düh, valamint az éntudatosítás különböző dimenzióit alkalmaztuk állapotjellemzőként. Az elemzésben nem minden esetben kaptunk szignifikáns összefüggéseket a mért változóink között, a Bonferronikorrekció alkalmazása miatt több esetben elvetettük az igazolt összefüggéseket.

Az STPI (Spielberger és mtsai 1983) állapotszorongás skálája leírja a személy szubjektív érzéseit (Collins és mtsai 2004) aggodalmaival, feszültségeivel, idegességével kapcsolatosan, kiemelve az adott helyzet hatását a szubjektív átélésre vonatkozóan. A feltételezéseknek megfelelően, amennyiben a flow élményt megtapasztalja a személy adott helyzetben, úgy a szorongás mint antiflow élményt (Csikszentmihalyi \& Selega Csikszentmihalyi, 1988; Csikszentmihalyi, 1975; Massimini, Csikszentmihalyi, \& Carli, 1987) nem kap teret, mivel a személy saját készségeihez illeszkedően optimális kihívással szembesül. Amennyiben elfogadjuk a feltételezést, hogy a flow szinkronizáció dimenziói a társas helyzetekben, közösen végzett tevékenység közben átélhető flow élményt támogatják, úgy, elvárásuknak megfelelően, ellentétes irányú, gyenge, illetve mérsékelt erősségú együttjárás volt tapasztalható az FSZK faktorai és az állapotszorongás mértéke között.

A düh az az érzelmi állapot, amely intenzitásában az enyhe irritációtól a düh és harag állapotáig változhat (Azevedo, Wang, Goulart, Lotufo, \& Benseñor, 2010), alapérzelemnek tekinthető (Ekman, 1999). Az érzelemszabályozó alrendszer részét képezi az ún. ingerlékenység gátlás faktor, amely a flow élmény fenntartásához járul hozzá, a zavaró tényezők kizárásával 
(Oláh, 2005). Tehát feltételeztük, hogy a düh intenzitásának növekedésével az átélt flow élmény csökken, így a flow-t támogató flow szinkronizációs faktorok mértéke is. A feltételezésnek megfelelően, a düh (Spielberger és mtsai 1983) és a flow szinkronizációs tényezők társas feladathelyzetben jellemzően gyenge, negatív irányú együttjárást mutatnak.

A DIH (Varga \& Józsa, 2013) feszültség skálája az interakció gördülékenysége, valamint a diád hangulata szempontjából negatív jellemzőket foglalja össze (félelem, feszültség, szorongás, kiszolgáltatottság stb.). Mivel a flow szinkronizációs faktorok a közös feladat során tapasztalt interakción alapulnak, így azok flow élményt támogató hatásához szükséges az interakció gördülékenysége és fennmaradása. Az elemzések alapján jellemzően közepes és gyenge szignifikáns összefüggések találhatók az FSZK és a DIH feszültség skálája között, ezért a feszültség az antiflow állapot egyik indikátoraként fogható fel.

Az éntudatosítás (Fenigstein és mtsai 1975) az én különböző aspektusaira való figyelmi fókuszálást jelenti, amely a flow állapotot átélő személynél eltûnik (Nakamura \& Csikszentmihalyi, 2002), hiszen a személy a kihívást jelentő tevékenységre koncentrál. A személyes éntudatosítás tartománya a fokális ingerek, diffúz belső állapotok, motívumok, valamint az önreflexió kategóriái mentén különíthető el, míg a társas éntudatosítás az én nyilvános aspektusaira (megjelenés, stílus, nyílt viselkedés) irányuló figyelmet foglalja össze (Buss, 1980). A szorongás speciális, társas aspektusát vizsgálja az Éntudatosság Kérdőív (Fenigstein és mtsai 1975) társas szorongás faktora. Amennyiben az éntudatosítás valamely aspektusa aktiválódik, szociális szorongás (Leary \& Kowalski, 1997) is kapcsolódhat hozzá, leginkább akkor, amikor a személy motivált arra, hogy a környezete által kívánatosnak tartott benyomást keltse magáról, azonban nem biztos benne, hogy képes lesz ezt megvalósítani. Mivel optimális élmény átélése közben a személy és a tevékenység összeolvad (Engeser \& Rheinberg, 2008), ezért flow élmény átélése mellett az éntudatosítástól való különbözőségét várjuk el. Mivel azt várjuk, hogy a flow szinkronizációs faktorok a flow élmény átélését támogassák a közös, együttmúködést igénylő feladathelyzetben, úgy az éntudatosítással való összefüggése az optimális élmény átélését gátolná. Jelen vizsgálatban gyenge együttjárást találtunk az éntudatosítás társas aspektusa és a flow szinkronizációs faktorok között, tehát hipotézisünk nagyrészt beigazolódott. A társas szorongás állapota jellemzően fordított irányú, gyenge együttjárást mutatott a flow szinkronizáció faktoraival, tehát egymástól jól elkülöníthető konstruktumokról beszélhetünk. Feltehetóen a flow szinkronizáció azért nem kapcsolódik az állapotszintú szorongás átéléséhez, a még megjelenő társas helyzet ellenére sem, mert nem jelennek meg olyan tényezők a kihívást jelentő helyzetben, amelyek az éntudatosítás különböző aspektusait felerősítenék (Fenigstein és mtsai 1975). 
A Flow Szinkronizáció Kérdőív célja, hogy azokat a faktorokat ragadja meg, amelyek a közös interakcióban végzett, kihívást jelentő feladatban tapasztalható áramlat élményt támogathatják. Eredményeink alapján elmondható, hogy az FSZK belsó megbízhatósága és validitása megfelelő, tehát a pszichometriai elvárásoknak eleget tesz. Ugyanakkor, a vizsgálat hiányosságait is meg kell fontolnunk. Jelen validitásvizsgálat korlátai közé tartozik a mintavétel és a minta jellege, mivel nem valószínúségi alapon történt a mintaválasztás, és nem reprezentatív a magyarországi felnőtt lakosságára nézve, továbbá a vizsgálatban szerepló minta az átlagéletkor alapján a fiatal felnőttek csoportjába tartozik. Az elemzés során alkalmazott skálák nem követték a normális eloszlást, így kevésbé érzékeny, robusztus próbákat alkalmaztunk az elemzéshez. Több esetben nem kaptunk szignifikáns együttjárást a vizsgált skálák között, tehát az összefüggések nem minden esetben tekinthetók igazoltnak. Ugyan az elemzésekhez szükségünk volt a nagy mintaelemszámhoz, amelyet kérdőíves módszerrel biztosítottunk, a retrospektív válaszadás torzíthatja az adatokat (Hassan, 2005), amelyet a szituációs leírás biztosításával igyekeztünk csökkenteni (Novak \& Hoffman, 1997). A jövőbeni kutatások során szükség van a vizsgálati helyzetek utáni azonnali élménymonitorozásra, a visszaidézési torzítás kiküszöbölésére (Hassan, 2005).

A Flow Szinkronizáció Kérdőív pszichometriai vizsgálatával célunk egy olyan stabil méróeszköz fejlesztése volt, amely a társas interakcióval kísért áramlat élmény hozzáadott jellemzőit kívánja megragadni, megfelelő módon operacionalizálni, ezáltal is hozzájárulva a jelenség minél pontosabb vizsgálatához.

\section{Irodalom}

Ackerman, M., \& Bargh, J.A. (2010). Two to Tango: Automatic Social Coordination and the Role of Felt Effort. In B. Bruya (Ed.), Effortless Attention - A New Perspective in the Cognitive Science of Attention and Action (335-371). Cambridge: The MIT Press

Aron, E.N., \& Aron, A. (1996). Love and expansion of the self: The state of the model. Personal Relationships, 3(1), 45-58.

Azevedo, F.B. de, Wang, Y.-P., Goulart, A.C., Lotufo, P.A., \& Benseñor, I.M. (2010). Application of the Spielberger's State-Trait Anger Expression Inventory in clinical patients. Arquivos de Neuro-Psiquiatria, 68(2), 231-234.

Bakker, A.B. (2005). Flow among music teachers and their students: The crossover of peak experiences. Journal of Vocational Behavior, 66(1), 26-44.

Bernieri, F.J., Davis, J.M., Rosenthal, R., \& Knee, C.R. (1994). Interactional Synchrony and Rapport: Measuring Synchrony in Displays Devoid of Sound and Facial Affect. Personality and Social Psychology Bulletin, 20(3), 303-311.

Brown, L.H., Silvia, P.J., Myin-Germeys, I., \& Kwapil, T.R. (2007). When the Need to Belong Goes Wrong - The expression of social anhedonia and social anxiety in daily life. Psychological Science, 18(9), 778-782. 
Buss, A.H. (1980). Self-consciousness and Social Anxiety. New York: W.H. Freeman \& Co Ltd.

Campos, J.J., \& Sternberg, C.R. (1981). Perception, appraisal and emotion: The onset of social referencing. In M.E. Lamb, \& L.R. Sherrod (Eds.), Infant social cognition: Empirical and theoretical considerations (273-314). Hillsdale: Lawrence Erlbaum Associates

Chen, H., Wigand, R.T., \& Nilan, M. (2000). Exploring Web users' optimal flow experiences. Information Technology \& People, 13(4), 263-281.

Clark, L.A., \& Watson, D. (1995). Constructing validity: Basic issues in objective scale development. Psychological Assessment, 7(3), 309-319.

Collins, R.P., Litman, J.A., \& Spielberger, C.D. (2004). The measurement of perceptual curiosity. Personality and Individual Differences, 36(5), 1127-1141.

Csikszentmihalyi, M. (1975). Beyond boredom and anxiety. San Francisco: Jossey-Bass Publishers

Csikszentmihalyi, M. (1990). Flow: The Psychology of Optimal Experience. New York: Harper \& Row

Csikszentmihalyi, M., \& Nakamura, J. (2010). Effortless attention in everyday life: A systematic phenomenology. In B. Bruya (Ed.), Effortless Attention - A New Perspective in the Cognitive Science of Attention and Action (179-189). New York: The MIT Press

Csikszentmihalyi, M., \& Selega Csikszentmihalyi, I. (Eds.). (1988). Optimal experience: Psychological studies of flow in consciousness. Cambridge: Cambridge University Press

Donaldson, S.I., Dollwet, M., \& Rao, M.A. (2015). Happiness, excellence, and optimal human functioning revisited: Examining the peer-reviewed literature linked to positive psychology. The Journal of Positive Psychology, 10(3), 185-195.

Dumas, G., Nadel, J., Soussignan, R., Martinerie, J., \& Garnero, L. (2010). Inter-Brain Synchronization during Social Interaction. PLOS ONE, 5(8), e12166.

Ekman, P. (1999). Basic emotions. In T. Dalgleish, \& M. Power (Eds.), Handbook of Cognition and Emotion (45-60). New York: John Wiley \& Sons, Inc.

Engeser, S., \& Rheinberg, F. (2008). Flow, performance and moderators of challenge-skill balance. Motivation and Emotion, 32(3), 158-172.

Engeser, S., \& Schiepe-Tiska, A. (2012). Historical lines and overview of current research on flow. In S. Engeser (Ed.), Advances in Flow Research (1-22). New York: Oxford University Press

Fenigstein, A., Scheier, M.F., \& Buss, A.H. (1975). Public and private self-consciousness: Assessment and theory. Journal of Consulting and Clinical Psychology, 43(4), 522-527.

Ghasemi, A., \& Zahediasl, S. (2012). Normality tests for statistical analysis: a guide for non-statisticians. International Journal of Endocrinology and Metabolism, 10(2), 486-489.

Graham, J.M. (2008). Self-expansion and flow in couples' momentary experiences: an experience sampling study. Journal of Personality and Social Psychology.

Hassan, E.S. (2005). Recall Bias can be a Threat to Retrospective and Prospective Research Designs. The Internet Journal of Epidemiology, 3(2), 1-7.

Hatfield, E., Cacioppo, J.T., \& Rapson, R.L. (1994). Emotional contagion. Current Directions in Psychological Science.

Hektner, J.M., Csikszentmihalyi, M., \& Schmidt, J.A. (2007). Experience Sampling Method: Measuring the Quality of Everyday Life. Thousand Oaks, London, New Delhi: Sage Publications

Hilsenroth, M.J., Segal, D.L., \& Hersen, M. (2003). Comprehensive Handbook of Psychological Assessment. In G. Goldstein, S.R. Beers, \& M. Hersen (Eds.), Assessment (Vol. 2). Hoboken, NJ, USA: John Wiley \& Sons, Inc.

Kashdan, T.B., \& Steger, M.F. (2011). Challenges, pitfalls, and aspirations for positive psychology. In K.M. Sheldon, T.B. Kashdan, \& M.F. Steger (Eds.), Designing positive psychology: Taking stock and moving forward (9-21). New York: Oxford University Press 
Kaye, L.K., \& Bryce, J. (2012). Putting the "fun factor" into gaming: The influence of social contexts on experiences of playing videogames. International Journal of Internet Science, $7(1), 1-41$.

Leary, M.R., \& Kowalski, R.M. (1997). Social Anxiety (Emotions and Social Behavior). New York: The Guilford Press

Magnusson, D., \& Stattin, H. (1998). Person context interaction theories. In Handbook of Child Psychology. Vol. 1: Theoretical Models of Human Development (685-759). New York: Wiley

Magyaródi, T. (2014). Flow synchronization related to flow and performance. In A. Oláh, \& H. Nagy (Eds.), Flow, emotional intelligence and psychological immunity. Empirical studies in positive psychological perspective (105-114). Budapest: Eötvös Kiadó.

Magyaródi, T., Nagy, H., Soltész, P., Mózes, T., \& Oláh, A. (2013). Egy újonnan kidolgozott Flow Állapot Kérdőív kimunkálásának és pszichometriai jellemzőinek bemutatása. Pszichológia, 33(1), 15-36.

Magyaródi, T., \& Oláh, A. (2015a). A cross-sectional survey study about the most common solitary and social flow activities to extend the concept of optimal experience. Europe's Journal of Psychology, 11(4), 632-650.

Magyaródi, T., \& Oláh, A. (2015b). Flow Szinkronizáció Kérdőív: az optimális élmény mechanizmusának mérése társas interakciós helyzetekben. Mentálhigiéné és Pszichoszomatika, 16(3), 271-296.

Maslow, A.H. (1962). Toward a Psychology of Being. Princeton: D. Van Nostrand Company.

Massimini, F., \& Carli, M. (1988). The systematic assessment of flow in daily experience. In M. Csikszentmihalyi, \& I. Selega Csikszentmihalyi (Eds.), Optimal experience: Psychological studies of flow in consciousness (288-318). New York: Cambridge University Press

Massimini, F., Csikszentmihalyi, M., \& Carli, M. (1987). The monitoring of optimal experience. A tool for psychiatric rehabilitation. The Journal of Nervous and Mental Disease, 175(9), 545-549.

Massimini, F., \& Delle Fave, A. (2000). Individual development in a bio-cultural perspective. American Psychologist, 55, 24-33.

McMahan, R.P., Ragan, E.D., Leal, A., Beaton, R.J., \& Bowman, D.A. (2011). Considerations for the use of commercial video games in controlled experiments. Entertainment Computing, 2(1), 3-9.

Mérei, F. (1947). Az együttes élmény. Budapest: Officina

Moller, A.C., Meler, B.P., \& Wall, R.D. (2010). Developing an experiemental induction of flow: Effortless action in the lab. In B. Bruya (Ed.), Effortless Attention: A New Perspective in the Cognitive Science of Attention and Action (191-213). New York: The MIT Press

Montgomery, H., Sharafi, P., \& Hedman, L.R. (2004). Engaging in activities involving information technology: dimensions, modes, and flow. Human Factors, 46(2), 334-348.

Nakamura, J., \& Csikszentmihalyi, M. (2002). The concept of flow. In C.R. Snyder, \& S.J. Lopez (Eds.), Handbook of Positive Psychology (89-105). New York: Oxford University Press

Novak, T.P., \& Hoffman, D.L. (1997). Measuring the flow experience among web users. Paper Presented at Interval Research Corporation, July 31, 1997. Letöltve: 2016. 01. 01jén: http:/ / citeseerx.ist.psu.edu/viewdoc/download?doi=10.1.1.89.1411\&rep=rep1\&t ype $=$ pdf

Nowak, A., Lewenstein, M., \& Vallacher, R.R. (1994). Toward a dynamical social psychology. In R.R. Vallacher, \& A. Nowak (Eds.), Dynamical Systems in Social Psychology (279-293). San Diego: Academic Press

Oláh, A. (1987). Az állapot-vonás személyiség kérdőív szorongás, düh és kíváncsiság skáláinak tesztkönyve. Budapest: Munkaügyi Kutatóintézet 
Oláh, A. (2005). Érzelmek, megküzdés és optimális élmény: belső világunk megismerésének módszerei. Budapest: Trefort Kiadó

Pace, S. (2004). A grounded theory of the flow experiences of Web users. International Journal of Human-Computer Studies, 60(3), 327-363.

Rich, G.J. (2013). Finding Flow: The History and Future of a Positive Psychology Concept. In J. D. Sinnott (Ed.), Positive Psychology: Advances in Understanding Adult Motivation (43-60). New York: Springer.

Riva, G., Waterworth, J.A., Waterworth, E.L., \& Mantovani, F. (2011). From intention to action: The role of presence. New Ideas in Psychology, 29(1), 24-37.

Rogers, C.R. (1961). On becoming a person. A Therapist's View of Psychoterapy. Boston: Houghton Mifflin Company

Rózsa, S., Reinhardt, M., \& Kulcsár, Zs. (2006). A poszttraumás növekedés feltételeinek empirikus vizsgálata. In Zs. Kulcsár, S. Rózsa, \& M. Reinhardt (Szerk.), A poszttraumás növekedés feltételei és empirikus vizsgálata (53-71). Budapest: Trefort Kiadó

Schmidt, R.C., Morr, S., Fitzpatrick, P., \& Richardson, M.J. (2012). Measuring the dynamics of interactional synchrony. Journal of Nonverbal Behavior, 36(4), 263-279.

Seligman, M.E.P., \& Csikszentmihalyi, M. (2000). Positive psychology - An introduction. American Psychologist, 55(1), 5-14.

Sheldon, K.M., \& Kasser, T. (2001). Goals, congruence, and positive well-being: New empirical support for humanistic theories. Journal of Humanistic Psychology, 41(1), 30-50.

Spielberger, C.R., Gorsuch, R.L., Lushene, R., Vagg, P.R., \& Jacobs, G.A. (1983). Manual for the State-Trait Anxiety Inventory. Palo Alto: Consulting Psychologist Press

Tenenbaum, G., Fogarty, G.J., \& Jackson, S.A. (1999). The flow experience: a Rasch analysis of Jackson's Flow State Scale. Journal of Outcome Measurement, 3(3), 278-294.

Trevarthen, C. (1980). The foundations of intersubjectivity: Development of interpersonal and cooperative understanding in infants. In D.R. Olson (Ed.), The social foundation of language and thought (316-342). New York: Norton

Ulrich, M., Keller, J., Hoenig, K., Waller, C., \& Grön, G. (2014). Neural correlates of experimentally induced flow experiences. NeuroImage, 86, 194-202.

Varga, K., \& Józsa, E. (2013). Új módszer a kétszemélyes interakciók szubjektív értékelésére: A Diádikus Interakciós Harmónia kérdőív. Magyar Pszichológiai Szemle, 68(3), 419-440.

Varga, K., Józsa, E., Bányai, É.I., \& Gősi-Greguss, A.C. (2012). Phenomenological synchrony and hypnotic susceptibility. Contemporary Hypnosis and Integrative Therapy, 29(2), 156-168.

Varga, K., Józsa, E., \& Urbán, R. (2002). A közös Rorschach vizsgálati helyzet alkalmazása a diádikus interakciók élményvilágában megmutatkozó harmónia vizsgálatára. In E. Bagdy (Ed.), Párkapcsolatok dinamikája (178-185). Budapest: Animula Kiadó

Walker, C.J. (2010). Experiencing flow: Is doing it together better than doing it alone? The Journal of Positive Psychology, 5(1), 3-11.

Wolf, E.J., Harrington, K.M., Clark, S.L., \& Miller, M.W. (2013). Sample Size Requirements for Structural Equation Models: An Evaluation of Power, Bias, and Solution Propriety. Educational and Psychological Measurement, 76(6), 913-934.

\section{Szerzói munkamegosztás}

Magyaródi Tímea: elméleti és kutatási koncepció megalkotása, kutatástervezés, kézirat megszövegezése, statisztikai elemzések, eredmények értelmezése.

Dr. Oláh Attila: elméleti koncepció, hipotézisek megfogalmazása, kutatástervezés, a kézirat ellenőrzése. 


\section{Nyilatkozat érdekütközésról}

A szerzők ezúton kijelentik, hogy esetükben nem állnak fenn érdekütközések.

\section{Psychometric Properties of the Flow Synchronization Questionnaire: Reliability and Validity Testing

\author{
MAGYARÓDI, TÍMEA - OLÁH, ATTILA
}

Theoretical background: Human interactions can be described through synchronization and coordination tendencies, even in case of the subjective experiences. Earlier results suggest that in a common activity a more intense flow experience can be found, than in a solitary situation. We labelled the contributing factors to this phenomenon as flow synchronization, and developed the Flow Synchronization Questionnaire (FSyQ) for its measurement.

Aim: The aim of the present study is the analysis of the psychometric characteristics of the Flow Synchronization Questionnaire: the reliability and validity of the scales.

Methods: In this online, cross-sectional survey study we used different questionnaires about the constructs as criterion factors (flow, characteristics of dyadic interaction, anxiety, selfconsciousness). 367 adult participants took part in the research $\left(\mathrm{M}_{\text {age }}=28.5\right.$ years, $\mathrm{SD}_{\text {age }}=$ 12.89 years).

Results: According to the results the internal consistency of the FSyQ scales are appropriate, and the five-factor structure is supported. $\left(\chi^{2}(336)=857.27, \mathrm{p}<.001, \mathrm{CMIN} / \mathrm{df}=2.55\right.$, $\mathrm{TLI}=.900, \mathrm{CFI}=.911$, RMSEA $=.065)$. The criterion validity testing has the expected results: convergent validity was proved by the association between the FSyQ factors and flow, the subjective experiences of dyadic interaction, curiosity, and the discriminant validity was supported by their independence from self-consciousness, tension, anxiety and anger.

Conclusions: The FSyQ might be an appropriate tool for the reliable and valid measurement of the flow synchronization dimensions.

Keywords: Flow Synchronization Questionnaire, reliability, validity 